\title{
T lymphocyte-derived demyelinating activity in multiple sclerosis patients in relapse
}

\author{
K SELMAJ,* R ALAM,* G D PERKIN, $\dagger$ F CLIFFORD ROSE* $\dagger$ \\ From the Academic Unit of Neuroscience, Charing Cross and Westminster Medical School,* and the \\ Department of Neurology, Regional Neurosciences Centre, Charing Cross Hospital, $\uparrow$ London, UK
}

SUMMARY Supernatants of cultured T lymphocytes of multiple sclerosis patients were tested for a demyelinating activity in rat cerebellum explant cultures. Supernatants of unstimulated T lymphocytes in seven out of 10 multiple sclerosis patients in relapse produced demyelination when checked by phase contrast microscopy. Supernatants of unstimulated T lymphocytes from healthy subjects did not produce demyelination, but when T cells were stimulated by phytohaemagglutinin (PHA), $50 \%$ of tested supernatants produced demyelination, which was, however, never as advanced as in multiple sclerosis supernatant treated cerebellum cultures. The demyelinating activity proved to be heat labile. Gel filtration study revealed two fractions of the demyelinating activity $12 \cdot 5-29 \cdot 0 \mathrm{kD}$ and $43 \cdot 0-66 \cdot 0 \mathrm{kD}$. The results suggest that lymphokines can be directly involved in the pathogenesis of demyelination in multiple sclerosis.

The primary pathological features of multiple sclerosis are demyelinating plaques randomly scattered throughout the white matter of the central nervous system (CNS). ${ }^{1}$ The aetiology of this disease is almost entirely unknown, but it has been long suspected that the immune system is involved in the pathomechanism leading to myelin loss. ${ }^{2}$ The active demyelinating plaques are prominently infiltrated with mononuclear cells, which though they include B cells and plasmocytes, ${ }^{3}$ consist predominantly of $\mathrm{T}$ cells. $^{4-7}$ The precise role of these cells and their significance in the immune reactions leading to the formation of demyelinating plaques is not fully understood. A previous report ${ }^{8}$ showed that the supernatants of cultured peripheral blood mononuclear cells of multiple sclerosis patients during an acute exacerbation consistently caused demyelination in vitro in nerve tissue organotypic culture.

We demonstrate here that the supernatants of cultured $\mathrm{T}$ lymphocytes of multiple sclerosis patients during an acute exacerbation produced, in the majority of cases, demyelination in vitro in nerve tissue organotypic culture. The gel filtration study showed that lymphokines are the most likely substances responsible for this demyelinating activity.

Address for reprint requests: Dr $\mathrm{K}$ Selmaj, Department of Neurology, Medical Academy of Lodz, 22 Kopcińskiego str, 90-153 Lodz, Poland.

Received 15 October 1985 and in revised form 19 February 1986. Accepted 25 April 1986.

\section{Material and methods}

\section{Subjects}

The lymphocyte donors were 10 multiple sclerosis patients seen in the Outpatient Department and wards of the Department of Neurology, Charing Cross Hospital, London UK. All patients had the remitting and relapsing form of definite multiple sclerosis ${ }^{9}$ and were studied in acute exacerbation no later than 2 weeks after the appearance of new neurological signs. There were eight females and two males in this group. Age ranging from 20 to 51 years (mean 32). Duration of the disease from 3 to 15 years. The clinical manifestations included pyramidal, cerebellar, brain stem and spinal cord signs. The patients were classified on the Kurtzke disability status scale from 3 to 7 grades. No patient had received steroids or immunosuppressive drugs for at least 3 months before sampling. Age- and sex-matched healthy subjects were used as controls in each case; blood samples were taken and processed at the same time as those of the patients with multiple sclerosis.

\section{Lymphocyte culture}

Peripheral blood was collected in heparinised tubes and mononuclear cells were isolated using Ficoll-paque (Pharmacia Fine Chemicals) gradient centrifugation (density 1.077 ) for $30 \mathrm{~min}$ at $400 \mathrm{~g} .{ }^{10}$ The adherent cells were removed by incubation of the cell suspension on plastic surfaces (Petri dishes) for $1 \mathrm{~h}$ at $37^{\circ} \mathrm{C}^{11}$ The nonadherent cells were then decanted and washed off twice with RPMI 1640 medium (GIBCO). Cell viability was checked with trypan blue. T lymphocytes were isolated by rosette technique. ${ }^{12}$ The rosette-forming cells (E-positive) were separated from the non-rosette forming cells (E-negative) by density gra- 
dient centrifugation (density 1.077 ), $12 \mathrm{~min}$ at $1000 \mathrm{~g}$. Epositive cells were cultured at a concentration of $5 \times$ $10^{5} / \mathrm{min}$ in RPMI 1640 medium plus $10 \%$ fetal calf serum (Sera-Lab) in flat bottom wells (NUNC, GIBCO) from 2 to 6 days. Phytohaemagglutinin (Wellcome Labs) at a concentration of $1 \mu \mathrm{g} / \mathrm{ml}$ was added to duplicate or triplicate cultures; simultaneously E-positive cells were cultured without PHA. E-negative cells were cultured at the same concentration and in the same conditions as the E-positive cells but only for 2 days and without PHA. The supernatants from both E-positive and E-negative cells were harvested and dialysed against distilled water and then against PBS. Supernatants were stored below $-20^{\circ} \mathrm{C}$ before use.

\section{Gel filtration}

The separation of the various major components of the $T$ lymphocyte supernatants was undertaken using gel filtration chromatography. A sample (4-6 ml) of T lymphocyte supernatant was layered on to $90 \mathrm{~cm} \times 2.5 \mathrm{~cm}$ Sephadex G-100 (Pharmacia Fine Chemicals) column. The flow rate $65 \mathrm{ml} \times$ $\mathrm{h}^{-1}$ was controlled by the LKB 2115 Multiperex pump and fractions were collected using an LKB 7000 Ultrorac fraction collector. The G-100 column was calibrated using a series of protein of known molecular weight (all obtained from Sigma Chemical Co): cytochrome C (12.5 kD), carbonic anhydrase (29.0 kD), ovalbumin $(43.0 \mathrm{kD})$, bovine serum albumin $(66 \cdot 0 \mathrm{kD})$ and blue dextran $(200 \cdot 0 \mathrm{kD})$.

\section{Rat cerebellum culture}

Neonatal rats (Wistar) on the day of birth were used for cerebellum culture. Each cerebellum was cut into eight parasagittal sections. These fragments were transferred on to collagen coated glass cover slips and maintained in nutrient medium consisting of $50 \%$ human heat inactivated serum, $40 \%$ Earle's lactoalbumin solution (Flow Labs) with $2 \%$ FCS, chicken embryo extract (Flow Labs), glucose at final concentration $600 \mathrm{mg} \%$, penicillin $(100 \mathrm{U} / \mathrm{ml})$ and strep- tomycin $(100 \mu \mathrm{g} / \mathrm{ml})$ in six well plates (Flow Labs). The supernatants of E-positive and E-negative cells were added to aliquots of usual feeding medium in a concentration of $50 \%, 25 \%, 10 \%$ and $5 \%$ after $16-18$ days in vitro (16-18 DIV) of cerebellum culture. Substantial myelination occurs in such cultures on 10-12 days, thus allowing us to investigate the effect of $T$ cell supernatants on already myelinated cultures. The chromatographic fractions were added in a concentration of $50 \%$, each sample being added to at least two cultures. As controls, sister cultures were fed with usual nutrient medium plus 50\% RPMI 1640 medium. By the end of $72 \mathrm{~h}$ observation the level of $\mathrm{K}^{+}$in culture medium was measured as a test for cell viability. For the same purpose some cultures were stained with trypan blue.

After $6,12,24,48$ and $72 \mathrm{~h}$ the living tested cerebellum cultures were examined for the presence of demyelination by reverse phase contrast microscope (Reichert). The readings were carried out independently by two observers using a coding system without knowing which $\mathrm{T}$ cell supernatant had been added to the culture.

The presence of myelin having been confirmed in selected untreated cultures by electron microscopy (Philips), these cultures were fixed in $2 \%$ phosphate buffered glutaraldehyde and were processed in the standard way for electron microscopy. $^{13}$

\section{Results}

Eighty per cent of E-positive cells reacted with monoclonal antibodies specific for pan- $T$ cell marker Leu-1 (Bio-Yeda Immunochemicals), whilst $85 \%$ of E-negative cells reacted with anti-human immunoglobulin serum (Coulter Electronic Ltd) specifically for B lymphocytes. Cell viability tested by trypan blue before and after cell separation was over

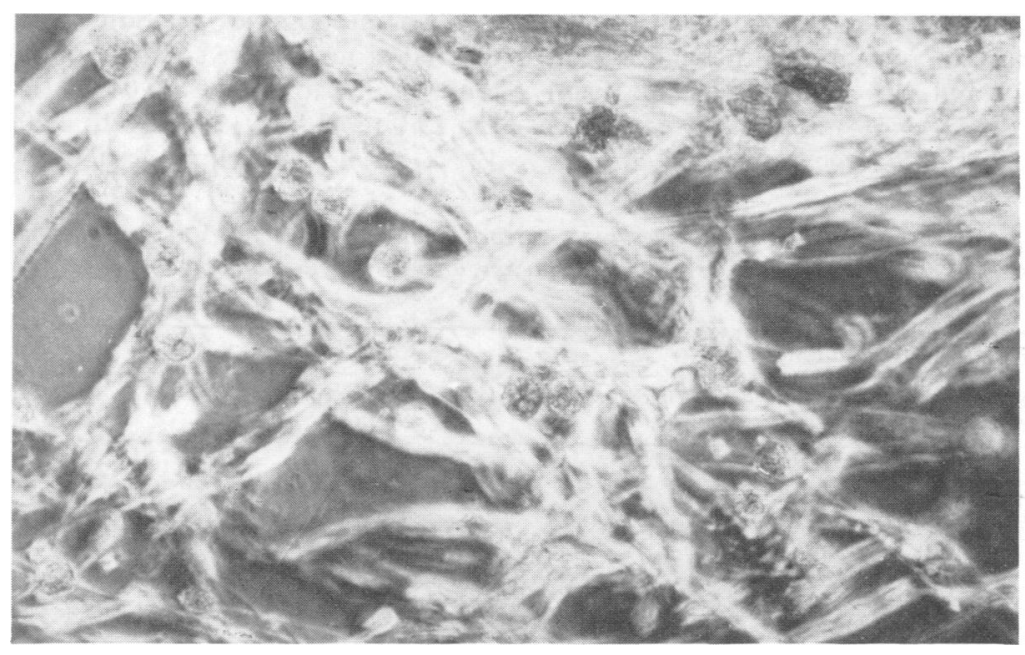

Fig 1 Outgrowths of axons lower down the explant. This area shows a field of several myelinated axons. Phase contrast; $(\times$ 1020.) 


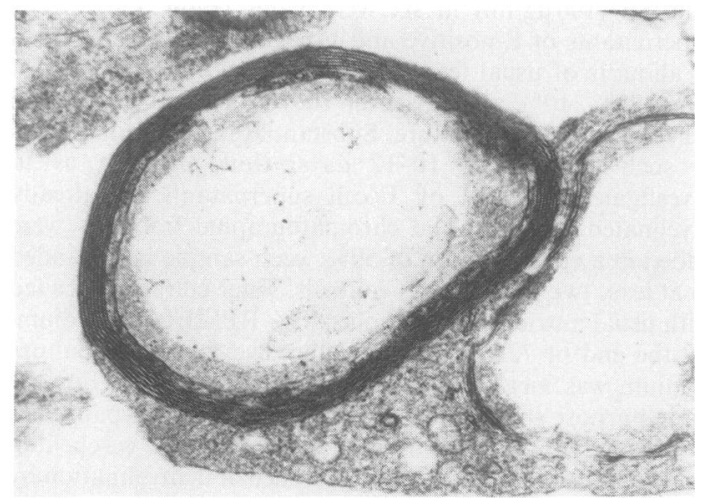

Fig 2 Electron micrograph of an intact myelin sheath (16 DIV) showing characteristic osmiophilic laminated membranes. (Uranyl acetate, lead citrate. $\times 48000$.)

$95 \%$ and, after the termination of cell culture, over $85 \%$.

The cerebellum cultures growing in standard conditions displayed features characteristic for such a system. ${ }^{13}$ Myelinated fibres were present within the neuroglia sheet surrounding the explant in a large proportion of the cultures after 10-12 DIV (fig 1). Myelin showed typical electron microscopic appearance (fig 2).

A summary of the effect of the supernatants tested is given in the table. Supernatants of unstimulated T lymphocytes of seven multiple sclerosis patients showed demyelinating activity, this reaction beginning by the end of $24 \mathrm{~h}$ of exposure to the supernatants. At about that time myelin sheaths appeared less bright and less distinct against the usual background. This process continued and apparently intact myelin gradually lost its characteristic birefringence under phase contrast microscope. By the end of $72 \mathrm{~h}$, myelin faded away and was indistinguishable from the background (fig 3). Not infrequently, necrotic cells were seen but not on a large scale when checked by trypan blue. The $\mathrm{K}^{+}$level in the incubation medium was also raised only slightly (less than $2 \%$ ) in tested cultures at the end of $72 \mathrm{~h}$ observation when compared with control cultures. The demyelinating activity was observed to the same degree in supernatants of $T$ lymphocytes cultured for 2 and for 6 days.

The supernatants added to the rat cerebellum cultures in a concentration of $25 \%$ of total nutrient medium continued to cause myelin damage in similar degree as in concentration of $50 \%$, but in a concentration of $10 \%$ no myelin destruction was observed. Supernatants of $\mathrm{T}$ lymphocytes of multiple sclerosis patients stimulated by phytohaemagglutinin showed similar but enhanced demyelinating activity.

Supernatants of unstimulated $\mathrm{T}$ lymphocytes of three multiple sclerosis patients did not show demyelinating activity as well as the control subjects. There were no clear differences in clinical status between these three multiple sclerosis patients and the seven patients who showed $\mathrm{T}$ cell derived demyelinating activity. Not infrequently, demyelinating changes were observed in cerebellum cultures exposed to supernatants of phytohaemagglutinin stimulated $T$ lymphocytes of control subjects, but never were these as advanced as in the multiple sclerosis patients.

Supernatants of unstimulated B lymphocytes of multiple sclerosis patients cultured for two days did not exhibit demyelinating activity in the rat cerebellum culture. The appearance of myelin in phase contrast microscopy did not differ from the appearance of myelin in control cultures. Similarly, no myelin damage was detected in nerve tissue culture treated with supernatants of B lymphocytes from control subjects.

Chromatographic fractions of $\mathrm{T}$ lymphocytederived proteins were combined in five groups as follows: I: 66.0 to about $100.0 \mathrm{kD}$, II: 43.0 to $66.0 \mathrm{kD}$, III: 29.0 to $43.0 \mathrm{kD}$, IV: 12.5 to $29.0 \mathrm{kD}$ and V: up to $12.5 \mathrm{kD}$. The demyelinating activity was detected in

Table Demyelinating activity of T lymphocyte supernatants. Score applied: - no changes, + minimial changes (less than $20 \%$ of axons affected),++ moderate changes (20-50\% of axons affected), +++ maximal changes (more than $50 \%$ of axons affected)

\begin{tabular}{|c|c|c|c|c|}
\hline \multirow[b]{2}{*}{ No } & \multicolumn{2}{|c|}{ Multiple sclerosis patients } & \multicolumn{2}{|c|}{ Control subjects } \\
\hline & $\begin{array}{l}\text { Spontaneous } \\
\text { activity }\end{array}$ & $\begin{array}{l}\text { PHA induced } \\
\text { activity }\end{array}$ & $\begin{array}{l}\text { Spontaneous } \\
\text { activity }\end{array}$ & $\begin{array}{l}\text { PHA induced } \\
\text { activity }\end{array}$ \\
\hline $\begin{array}{r}1 \\
2 \\
3 \\
4 \\
5 \\
6 \\
7 \\
8 \\
9 \\
10\end{array}$ & $\begin{array}{l}+++ \\
++ \\
+++ \\
+++ \\
++ \\
- \\
+++ \\
+++ \\
+\end{array}$ & $\begin{array}{l}+++ \\
++ \\
+++ \\
+++ \\
+++ \\
++ \\
+ \\
+++ \\
+++ \\
+\end{array}$ & $\begin{array}{l}- \\
\overline{-} \\
\overline{-} \\
\overline{-} \\
\bar{z} \\
\overline{-} \\
-\end{array}$ & $\begin{array}{l}- \\
+ \\
+ \\
+ \\
+ \\
+ \\
+ \\
+ \\
-\end{array}$ \\
\hline
\end{tabular}

PHA = phytohaemagglutinin. 


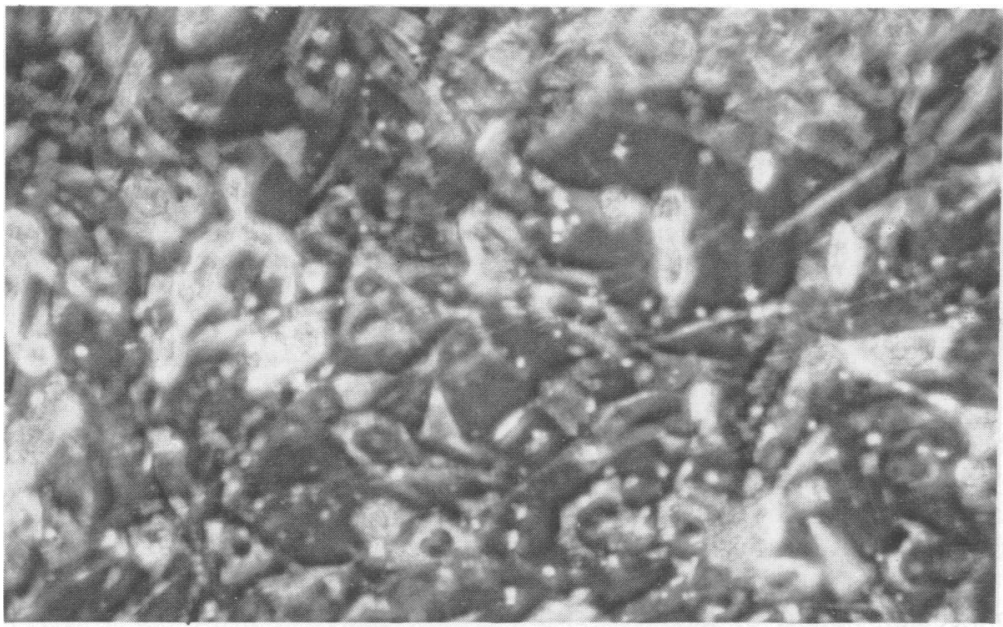

Fig 3 The culture from fig 1 treated with supernatant of multiple sclerosis patient $T$ lymphocytes for $72 \mathrm{~h}$. This area shows an extensive field of myelin destruction. Most myelin has been reduced to small refractile debris; (phase contrast; $\times 1020$.)

fraction II and IV (fig 4). The time of action and morphological features observed in the rat cerebellum cultures under phase contrast microscopy were similar to those described above for the crude $\mathrm{T}$ lymphocyte supernatants, but fraction II appeared to be more active in causing myelin damage. Necrotic cells were also more commonly observed in nerve tissue cultures treated with fraction II than with fraction IV.

\section{Discussion}

Whilst there are several mechanisms leading to demyelination in pathological conditions of the CNS, immunological mechanisms are of particular importance in primary demyelinating diseases, the commonest of which is multiple sclerosis. Immunologically mediated demyelination in experimental models is seen in the presence of antimyelin antibodies, ${ }^{14}$ as a result of cell-mediated cytotoxicity ${ }^{15}$ or as a consequence of antibody-dependent cytotoxicity, ${ }^{16}$ but there is no convincing evidence that any of these mechanisms is responsible for demyelination in multiple sclerosis. ${ }^{17}$

The results of this study may suggest another mechanism leading to immune mediated demyelination dependent on the soluble factors derived from $\mathrm{T}$ lymphocytes. Lymphokines are known to be intercellular regulatory factors, so that the possibility of interaction between lymphokines from multiple sclerosis $\mathrm{T}$ lymphocytes and the cells in nerve tissue culture have to be considered. From the theoretical point of view, two such interactions could have occurred in our experimental model. $T$ lymphocytes in culture pro- duce macrophage activation factor(s) ${ }^{18}$ which can drive and stimulate macrophages to phagocytosis as well as hydrolytic enzyme release. Phospholipases ${ }^{19}$ and proteases ${ }^{20}$ secreted by activated macrophages have been shown to mediate breakdown of isolated myelin and myelin basic protein, and morphological studies have implicated macrophages in the demye-

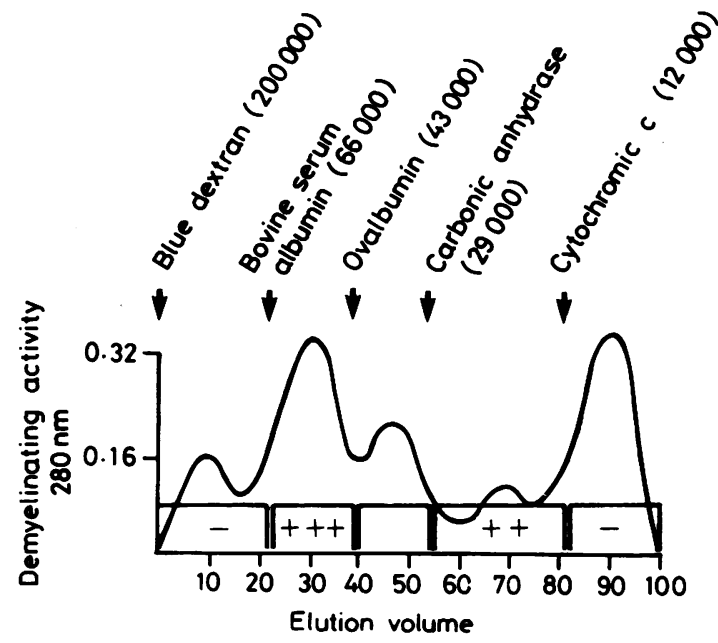

Fig 4 Lymphokine myelinotoxic activity in fractions obtained from Sephadex G-100 chromatography of $T$ lymphocyte supernatant of multiple sclerosis patients (4 subjects were studied). Optic density at $280 \mathrm{~nm}$. Score: - no changes, ++ moderate changes (20-50\% axons affected), +++ maximal changes (more than $50 \%$ axons affected) 
lination of multiple sclerosis. ${ }^{21}$ The molecular weight of macrophage activation factor seems to be heterogeneic ${ }^{22}$ and may overlap with the molecular weight of the chromatographic fractions causing demyelination in this study. Another cell potentially stimulated by $\mathrm{T}$ lymphocyte derived lymphokine is the astrocyte, which possesses hydrolytic enzymes capable of degrading myelin. ${ }^{23}$ Histochemical staining for various hydrolytic enzymes showed astrocytes as the main hydrolase-rich cells, apart from macrophages, in both plaque and periplaque tissue. ${ }^{23}$ Only recently has a relationship between astrocytes and immune cells been suggested by in vitro studies demonstrating lymphokine-enhanced proliferation of murine and rat astrocytes. ${ }^{24} 25$ Two distinct lymphokines are possible candidates for this interaction, glial cell stimulating factor ${ }^{24}$ and glial growth-promoting factor. $^{25}$ The molecular weight of glial cell stimulating factor overlaps with the molecular weight of the chromatographic fraction IV causing demyelination in this study. At this stage it is difficult to assess the role of astrocytes or macrophages in the lymphokine mediated demyelination seen in this study. However, another explanation for the observed demyelination in rat cerebellum culture might be a direct lymphokine myelinotoxic effect. Some lymphokines possess enzymatic activity which could produce myelin damage. The timing of demyelination after nerve tissue treatment with $T$ cell supernatants (24-72h) and the molecular weight of the demyelinating fractions suggests some similarities with lymphotoxin. ${ }^{26}$ Possible mechanisms related to lymphotoxin activity are an increased content of lysosomal enzymes ${ }^{27}$ or increased permeability to calcium ions, ${ }^{28}$ each of which could easily be involved in the pathomechanism of myelin damage. The production of lymphotoxin by lymph node cells of rats with experimental allergic encephalomyelitis may support this suggestion. ${ }^{29}$

In summary, we described a demyelinating activity of $T$ lymphocyte supernatant of multiple sclerosis patients in relapse. Gel filtration study revealed two fractions of demyelinating activity, $12 \cdot 5-29 \cdot 0 \mathrm{kD}$ and $43.0-66.0 \mathrm{kD}$. Whether this is a new lymphokine with demyelinating activity or a new property of an already known lymphokine is a subject for further study.

We are grateful to Professor R N Maini and Dr C Plater-Zyberk, Kennedy Institute of Rheumatology, London, for their help in lymphocyte cultures. We are also grateful to Professor J C Sloper and Dr T J Partridge, Charing Cross and Westminster Medical School, London, for giving us facilities for rat cerebellum cultures, and Dr J Moss for assistance with the electron microscopy. We thank Dr K Bradbury, Uni- versity of Leeds, for helpful discussion and assistance in selection of materials for presentation in this paper. We are grateful to Dr M Feldman, Charing Cross Sunley Research Centre, London, for discussion of our results.

This paper was supported by the British Council in a form of a British Council Fellowship to Dr K Selmaj.

\section{References}

1 Lumsden CE. The neuropathology of multiple sclerosis. In: Vinken PJ, Bruyn GW, eds. Handbook of Clinical Neurology, Vol 9. Amsterdam: North Holland, 1970: 217-309.

2 Raine CS. Biology of disease: analysis of autoimmune demyelination: its impact upon multiple sclerosis. $L a b$ Invest 1984;50:608-35.

3 Esiri M. Multiple sclerosis-a quantitative and qualitative study of immunoglobulin-containing cells in the central nervous system. Neuropathol App Neurobiol 1980;6:9-21.

4 Nyland H, Matre R, Mork S, Bjerke J-R, Nass A. T-lymphocyte subpopulations in multiple sclerosis. N Engl J Med 1982;307:1643-4.

5 Brinkman CJJ, Ter Laak HJ, Hommes OR, Poppema S, Delmotte P. T-lymphocyte subpopulations in multiple sclerosis. N Engl J Med 1982;307:1644-5.

6 Traugott U, Reinherz EL, Raine CS. Multiple sclerosis. distribution of cell subsets within active chronig lesions. Science 1983;219:308-10.

7 Traugott U, Reinherz EL, Raine CS. Multiple sclerosis $\overrightarrow{0}$ distribution of $\mathrm{T}$ cell subsets and Ia-positive macros phages in lesions of different ages. $J \cdot$ Neuroimmunot 1983;4:201-21.

8 Selmaj K, Alam R, Renkawek K, Kida E, Maszewska M, Rożniecki J. Studies on lymphokine-mediated demyelination in multiple sclerosis. $J$ Neurol 1985;232 Suppl: 195 .

9 McDonald IW, Halliday AM. Diagnosis and classification of multiple sclerosis. $\mathrm{Br}$ Med Bull 1977;33:4-8.

10 Boyum A. Isolation of lymphocytes, granulocytes and macrophages. Scand J Immunol 1976;5(Suppl 5):9-15.

11 Al-Ibrahim MS, Chandra R, Kishore R, Valentine FT, Lawrence HS. A micromethod for evaluation for the phagocytic activity of human macrophages by ingestion of radiolabelled polystyrene particles. $J$ Immunol Methods 1976;10:207-18.

12 Mahowlad ML, Handwerger BS, Carpertone EM Jr, Douglas SD. A comparative study of procedures for sheep erythrocyte-human-T-lymphocyte rosette formation. J Immunol Methods 1977;15:239-46.

13 Borstein MB, Murray MR. Serial observation on patterns of growth, myelin formation, maintenance and degeneration in culture of newborn rat and kitten cerebellum. J Biophysic Biochem Cytol 1958;4:499-504.

14 Grundke-Iqbal I, Raine CS, Johnson CS, Johnson AB, Brosnan CF, Borstein MB. Experimental allergic encephalomyelitis - characterization of serum factors causing demyelination and swelling of myelin. $J \mathrm{Neu}$ rol Sci 1981;50:63-79. 
15 Lumsden CE. The immunogenesis of multiple sclerosis plaque. Brain Res 1971;28:365-90.

16 Brosnan CF, Stoner GL, Bloom BR, Wisniewski HM. Studies on demyelination by activated lymphocytes in the rabbit eye. II. Antibody-dependent cell-mediated demyelination. J Immunol 1977;118:2103-10.

17 Waksman BH, Reynolds WE. Multiple sclerosis as a disease of immune regulation. Proc Soc Exp Biol Med 1984;175:282-94.

18 Gemsa D, Kubelka C, Debatin K-M, Krammer PH. Activation of macrophages by lymphokines from T-cell clones: evidence for different macrophageactivation factors. Mol Immunol 1984;21:1267-76.

19 Trotter J, Smith ME. Macrophage-mediated demyelination: the role of phospholipases. In: Alvord WC, Jr, Kies MW, Sucklin AJ, eds. Experimental Allergic Encephalomyelitis. A Useful Model for Mutiple Sclerosis. New York: Alan R Liss, 1984:55-60.

20 Cammer W, Bloom BR, Norton WT, Gorgon S. Degradation of basic protein of myelin by neutral proteases secreted by stimulated macrophages: a possible mechanism of inflammatory demyelination. Proc Natl Acad Sci USA 1978;75:1554-9.

21 Prineas J. Pathology of the early lesion in multiple sclerosis. Hum Pathol 1975;6:531-54.

22 Coleman DL, Culver KE, Ryan JL. Enhancement of macrophage immune and nonimmune receptor- mediated phagocytosis by a low molecular weight factor from resident thymocytes. J Immunol 1984; 133:3121-7.

23 Allen IV. Hydrolytic enzymes in multiple sclerosis. In: Zimmerman HM, ed. Progress in Neuropathology, Vol 5. New York: Raven Press, 1983:1-17.

24 Fontana A, Dubs R, Merchant R, Balsiger S, Grog PJ. Glial cell stimulating factor (GSF): a new lymphokine I. Cellular sources and partial purification of murine GSF, role of cytoskeleton and protein synthesis in its production. J Neuroimmunol 1981;2:55-70.

25 Merrill JE, Kutsunai S, Mohlstrom C, Hofman F, Groopman J, Golde DW. Proliferation of astroglia and oligodendrioglia in response to human $\mathrm{T}$ cellderived factors. Science 1984;224:1428-30.

26 Ruddle NH. Lymphotoxin redux. Immunol Today 1985;6:156-9.

27 Ruddle NH, Waksman BH. Cytotoxicity mediated by soluble antigen and lymphocytes in delayed hypersensitivity. J Exp Med 1968;128:1267-79.

28 Okomoto M, Mayer MM. Studies on the mechanism of action of guinea pig lymphotoxin II. Increase of calcium uptake in LT-damaged target cells. J Immunol 1978;120:279-85.

29 Ellison GW, Waksman BH, Ruddle NH. Experimental allergic encephalomyelitis and cellular hypersensitivity in vitro. Neurology 1971;21:778-82. 